\title{
Peningkatan Kualitas dan Kuantitas Nugget Lele dengan Menggunakan Mesin Mekanis
}

\author{
Tri Wahyudi ${ }^{1)}$, Silvia Uslianti ${ }^{2)}$ \\ ${ }^{1,2)}$ Program Studi Teknik Industri Jurusan Teknik Elektro \\ Fakultas Teknik, Universitas Tanjungpura \\ e-mail : triecell@yahoo.com ${ }^{1)}$, silvia.uslianti@gmail.com ${ }^{2}$
}

\begin{abstract}
Nugget ikan lele sayur merupakan salah satu inovasi olahan berbahan dasar ikan yang sangat menyehatkan, dikarenakan terbuat dari bahan-bahan yang segar, bergizi, dan tanpa diberikan MSG. Makanan ini sangat cocok dan disukai oleh anak-anak. Olahan ikan tersebut di buat oleh kelompok wanita tani Barokah dan pasokan ikan lele di pasok oleh kelompok wanita tani At'Taqwa.Berdasarkan hasil diskusi baik dengan mitra bahwa permasalahan prioritas yang akan diselesaikan adalah: PERTAMA, masalah mahalnya harga pakan ikan, mahalnya harga mesin pelet di pasaran dan belum mengetahui cara pembuatan pakan ikan. Solusi yang ditawarkan untuk kedua mitra adalah transfer ipteks, bantuan mesin pelet dan pelatihan pengoperasionalan mesin pelet beserta pelatihan pembuatan pakan ikan. Sedangkan KEDUA, bagaimana meningkatkan perekonomian masyarakat kelurahan banjar serasan dengan memanfaatkan hasil budidaya lele yang dikelola dengan mengembangkan atau mengolah menjadi Nugget yang memiliki nilai ekonomis dan dapat dikonsumsi oleh masyarakat sehingga roda perekonomian dapat berputar, gizi anak-anak masyarakat sekitar dapat terpenuhi dan menghindarkan anak-anak dari makanan/jajanan yang tidak sehat. Bantuan yang diberikan mesin pengaduk/penghancur ikan dan vacuum sealer.

Mesin pelet ikan lele, mesin pengaduk /penghancur ikan lele, serta mesin vacuum sealer dapat dimanfaat Mitra 1 dan 2 untuk proses produksi pelet dan nugget secara higienis sehingga permasalahan yang selama ini dihadapi para mitra dapat diurai dan diselesaikan dengan baik. Peningkatan keuntungan yang dirasakan mitra setelah adanya kegiatan lebih dari $50 \%$, dan keseluruhan kegiatan telah dilaksanakan dengan baik dan memperoleh sambutan yang sangat baik.
\end{abstract}

\section{Keywords-Nugget, Ikan Lele, Makanan Olahan}

\section{Pendahuluan}

Nugget ikan lele sayur merupakan salah satu inovasi olahan berbahan dasar ikan yang sangat menyehatkan, dikarenakan terbuat dari bahan-bahan yang segar, bergizi, dan tanpa diberikan MSG. Makanan ini sangat cocok dan disukai oleh anak-anak.
Mitra pertama dengan nama Kelompok Wanita Tani At'Taqwa yang beralamat di Jalan Tanjung Harapan, Kelurahan Banjar Serasan Kecamatan Pontianak Timur Kota Pontianak. Jarak tempuh antara Universitas Tanjungpura dengan Mitra pertama kurang lebih $12 \mathrm{~km}$ atau sekitar 40 menit jika ditempuh dengan menggunakan kendaraan bermotor.Ibu-ibu rumah tangga di Kelurahan Banjar Serasan yang mengelola pengarangan mereka dengan membudidayakan ikan lele dengan metode kolam terpal.Kolam terpal diyakini lebih praktis diterapkan dilahan terbatas serta pembuatan yang relatif lebih murah dibandingkan dengan kolam tembok sehingga sangat cocok untuk dikelola oleh ibu-ibu rumah tangga.Kolam terpal hanya diisi dengan ikan lele saja dan hanya untuk lele pembesaran, sehingga perawatan yang dilakukan dapat lebih terfokus kepada pemeliharaan pembesaran. Hanya saja karena berbagai faktor dan pertimbangan, mitra mengalihkannya pada keramba abung yang dipasang ditepian sungai Kapuas. Harga ikan lele dipasaran tergantung kepada besar kecilnya pasokan atau melimpah tidaknya produk dipasaran. Pada saat panen raya biasanya ikan lele hanya dapat di jual dengan kisaran harga Rp.18.000 s/d Rp.28.000, sehingga sangat tidak sebanding dengan harga pakan lele itu sendiri yang berkisar antara Rp.11.000 s/d Rp.26.000 perkilonya tergantung dari kualitas dari pakan.

Mitra kedua adalah Kelompok Wanita Tani Barokah yang beralamat di Jalan Tanjung Harapan Gang Budi Jaya Kelurahan Banjar Serasan Kecamatan Pontianak Timur Kota Pontianak.Jarak tempuh antara Universitas Tanjungpura dengan Mitra pertama kurang lebih $12 \mathrm{~km}$ atau sekitar 45 menit waktu yang diperlukan jika ditempuh dengan menggunakan kendaraan bermotor. Mitra kedua diketuai oleh ibu Rita, dengan sekretaris ibu Umi Halimah, bendahara ibu Ismiatun, dan anggota ibu Misnawati, Dede Suryani, Odita M Anggraini, Julianti, Aminah, Jarhanisah, dan ibu Halijah. Pembuatan Makanan (Nugget) berbahan dasar Ikan yang dilakukan oleh Kelompok Wanita Tani Barokah berawal dari banyaknya hasil tambak ikan di Kelurahan Banjar Serasan yang mengalami kesulitan dalam pemasaran, terutama hasil panen tambak dalam terpal yang di kelolah oleh ibu-ibu rumah tangga di sekitar lingkungan, serta bagaimana cara membuat anak-anak yang susah makan ikan menjadi gemar makan ikan meski pun dalam bentuk lain. 
Kelompok Wanita Tani yang tergabung didalam wilayah Kelurahan Banjar Serasan berinisiatif untuk memanfaatkan keadaan tersebut dengan mengembangkan usaha dengan memanfaatkan ikan lele yang melimpah tersebut, dengan mengolah ikan lele menjadi makanan olahan berbentuk nugget yang memiliki nilai ekonomis yang tinggi untuk meningkatkan taraf kehidupan warga di daerah Keluarahan Banjar Serasan khususnya peningkatan ekonomi keluarga anggota Kelompok Wanita Tani.

Beberapa permasalahan yang dihadapi oleh kelompok nelayan baik mitra 1 maupun mitra 2 sebagai berikut:

a. Mahalnya harga pakan ikan. Kebutuhan pakan untuk setiap bibit yang ditebar sebanyak 3000 ekor ikan, sanggup menghabiskan $\pm 600 \mathrm{~kg}$ pelet. Pakan tersebut bisa lebih ataupun kurang tergantung pada keadaan air, perawatan dan iklim. Tingginya permintaan pakan ikan tidak dibarengi dengan harga ikan. Besarnya kebutuhan pakan ikan dan semakin tingginya harga pakan menyebabkan usaha tambak ikan yang dikelola mitra sering kali mengalami kerugian dalam hal tenaga dan waktu yang dikeluarkan tidak seimbang dengan penerimaan. Pasokan pakan yang masih didatangkan dari luar pulau Kalimantan menyebabkan harga pakan terus berfluktuatif. Apabila terjadi keterlambatan pengiriman, maka berdampak pada kelangkaan pakan ikan sehingga harga pasaran pakan ikan menjadi tinggi. Saat ini harga pakan ikan untuk pembesaran berkisar Rp.11.000,- s/d Rp.18.000,- per kilo untuk kualitas biasa, sedangkan pakan ikan dengan protein tertinggi harganya diatas Rp.18.000,-. Harga pakan ikan tidak sebanding dengan harga ikan segar yang dijual dengan harga berkisar antara Rp. $18.000 \mathrm{~s} / \mathrm{d}$ Rp. 28.000 per kilogram.

b. Belum mengetahui cara membuat pakan ikan. Tingkat pertumbuhan ikan tergantung kepada tingkat kebutuhan ikan terhadap pakan dan kandungan gizi pada pakan. Tingginya harga pakan ikan yang berkualitas baik menyebabkan Mitra mempunyai keinginan untuk bisa membuat pakan ikan sendiri, akan tetapi mereka belum mengetahui bagaimana cara membuat pakan ikan yang baik sehingga dapat menyamai mutu pakan ikan yang ada di pasaran. Melihat kondisi ini, apabila mitra mampu membuat pelet sendiri dengan sumber bahan baku lokal, maka tentu saja biaya produksi dapat ditekan, sehingga penghasilan mereka dapat meningkat. Kalimantan Barat memiliki sumber bahan baku pakan yang cukup melimpah diantaranya dedak sisa penggilingan padi dan jagung, dan lain-lain yang dapat dijadikan bahan baku untuk pembuatan pelet ikan.

c. Mahalnya harga mesin pelet di pasaran dan belum mengetahui cara pembuatan mesin pelet. Harga mesin Pelet yang ada di pasaran berkisar Rp.13.675.000 s.d. Rp.20.000.000, bias untuk pembuatan pelet terapung dan tenggelam. Harga tersebut belum termasuk ongkos kirim dan pajak pembelian barang. Tingginya harga mesin pellet menyebabkan mitra tidak mampu untuk membelinya. Untuk membuat sendiri mesin pellet mereka belum mengetahui karena keterbatasan informasi yang dimiliki. Mereka mengharapkan adanya bantuan dari Pemda. Dengan adanya mesin pelet maka diharapkan para mitra sanggup untuk membuat pelet pakan ikan sendiri dengan memanfaatkan bahan-bahan yang melimpah di sekitar lingkungan tambak seperti bekatul, dan lain-lain.

d. Keinginan mitra untuk dapat mengatasi murahnya harga jual lele dipasaran, bahkan kadang juga berfluktuatif akibat melimpahnya pasokan lele. Bagaimana mengolah ikan lele tersebut sehingga memiliki nilai ekonomis yang tinggi, sehingga produk yang dapat dijual tidak hanya lele segar.

e. Kita ketahui bersama ikan lele segar sangat baik dikonsumsi oleh anak-anak, khususnya untuk mencukupi nutrisi untuk perkembangan anak-anak, tetapi sangat disayangkan lele yang dibudidaya sulit untuk diterima untuk langsung dikonsumsi, khususnya oleh anak-anak dikarenakan kadang memiliki bentuk yang tidak menarik, dan rasa atau aroma lumpur yang tidak mampu menggugah selera makan akan-anak dil lingkungan sekitar Kelurahan Banjar Serasan.

f. Ibu-ibu Kelompok Wanita Tani belum mampu mengembangkan olahan higienis berbahan baku daging ikan lele segar menjadi olahan nugget skala industri kecil menengah untuk dapat dikembangkan menjadi panganan olahan komersil yang memiliki daya saing tinggi. Peningkatan Mutu dalam perluasan pemasaran,terutama dalam hal penampilan bentuk dan produksi yang cepat dan tepat dalam memenuhi permintaan Konsumen,ini juga bertujuan untuk meningkatkan mutu dalam persaingan dengan produksi Nuggets dari luar.

Berdasarkan hasil diskusi baik dengan mitra 1 maupun dengan mitra 2 bahwa permasalahan prioritas yang akan diselesaikan adalah: Mitra PERTAMA, masalah mahalnya harga pakan ikan, mahalnya harga mesin pelet di pasaran dan belum mengetahui cara pembuatan pakan ikan. Solusi yang ditawarkan untuk kedua mitra adalah transfer ipteks pembuatan mesin pelet danpelatihan pengoperasionalan mesin pelet beserta pelatihan pembuatan pakan ikan menggunakan mesin pelet. Sedangkan Mitra KEDUA, bagaimana meningkatkan perekonomian masyarakat kelurahan banjar serasan dengan memanfaatkan hasil budidaya lele terpal yang dikelola dengan mengembangkan atau mengolah menjadi Nugget yang memiliki nilai ekonomis dan dapat dikonsumsi oleh masyarakat sehingga roda perekonomian dapat berputar, gizi anakanak masyarakat sekitar dapat terpenuhi dan menghindarkan anak-anak dari makanan/jajanan yang tidak sehat.

\section{Teori Dasar}

Nugget merupakan salah satu produk olahan makanan setengah jadi yang terbuat dari daging giling dengan campuran bumbu dan merupakan produk emulsi (Rini, 2001).

Salah satu hasil diversifikasi produk perikanan adalah nugget ikan layang (Decapterus sp.) yang 
disubtitusi dengan tepung ubi jalar (Ipomea batatas L). Bahan baku yang digunakan pada pembuatan nugget adalah ikan layang yang diperoleh di Tempat Pelelangan Ikan (TPI) Provinsi Gorontalo dengan ukuran ikan 20-25 $\mathrm{cm}$. Bahan pengikat dan bahan tambahan yang digunakan adalah tepung tapioka, tepung ubi jalar, tepung roti, garam $\mathrm{NaCl}$, telur ayam, minyak goreng, bawang putih, lada, gula, air bersih. Untuk uji analisa proksimat bahan yang digunakan adalah K2SO4, $\mathrm{H} 2 \mathrm{SO} 4, \mathrm{HgO}, \mathrm{NaOH}, \mathrm{HNO} 3, \mathrm{HCl}, \mathrm{NHeksana}$, Aquades 98\%..Hasil uji metode Bayes menunjukkan bahwa Formula B (1:1)adalah produk nugget terpilih dengan nilai bobot tertinggi 2,30. Nugget terpilih mengandung air 45,07\% (bb), abu 1,96\% (bb), protein 14,01\% (bb), lemak 19,90\% (bb), dan karbohidrat $19,06 \%$ (bb). Karakteristik mutu hedonik terhadap nugget terpilih berada pada kriteria penampakan: utuh, rapi, kurang bersih, homogen, kuning kemerahan; warna: kuning kecoklatan; rasa: enak, spesifik ikan dan ubi jalar kurang kuat, gurih; aroma: segar, spesifik ikan dan ubi jalar kurang kuat; dan tekstur: kenyal, kompak, tidak padat (Utiarahman G, dkk, 2013).

Proses pembuatan nugget komposit ini, dibagi atas dua tahap yaitu tahap proses pembuatan nugget komposit dengan perlakuan komposisi daging ikan hiu dan ampas tahu terhadap tepung tapioka . Dari hasil penelitian dapat disimpulkan bahwa perlakuan terbaik adalah nugget komposit jenis A (40\% ampas tahu, 35\% daging ikan hiu) dengan komposisi gizi yaitu kadar air, abu, lemak, protein, karbohidrat, kalsium, nilai kalori, dan asam amino masing-masing 63,8\%, 1,5\%, 0,08\%, $8,7 \%, 25,9 \%, 0,25 \pm 0,0064 \mathrm{mg} / \mathrm{g}$ dan $44586,9 \mathrm{kkal} / 100 \mathrm{~g}$ (Mushollaeni W dan Tirtosastro S, 2007)

Dari permasalahan diatas peneliti mencoba untuk mengembangkan potensi dari kan lele dari pembesaran lele sampai dengan produk olahan nugget berbahan dasar ikan lele dan sayur, dengan tahapan sebagai berikut:

\section{A. Tahapan Metode Pelaksanaan Kegiatan}

Tahapan metode palaksanaan kegiatan yang dilakukan untuk mitra 1, adalah sebagai berikut :

a. Persiapan bahan. Bahan-bahan yang diperlukan untuk membuat mesin pelet ikan dan proses pembuatan pellet ikan, adalah sebagai berikut:

1) Tepung ikan

2) Bekatul

3) EM4

4) Essent

5) Vitamin

6) Tepung tapioka

b. Peralatan yang digunakan untuk membuat mesin pelet ikan sebagai berikut:

1) Mesin Pelet

2) Timbangan

3) Sendok Plastik

4) Baskom

Tahapan metode palaksanaan kegiatan untuk mitra 2, adalah sebagai berikut : a. Persiapan bahan. Peralatan yang digunakan untuk membuat nugget ikan lele sayur sebagai berikut:

1) Ikan lele

2) Sayuran: wortel, daun bawang, dsb.

3) Tepung tapioka

4) Tepung terigu

5) Tepung panir

6) Telur

7) Minyak goreng

8) Bumbu dapur

9) Plastik vacuum/packaging

b. Peralatan yang digunakan untuk pembuatan nugget ikan lele sayur, sebagai berikut:

1) Mesin Pengaduk/Penghancur ikan

2) Vacuum Sealer Ikan lele

Proses pembuatan pelet ikan dan pembuatan nugget ikan dilakukan oleh semua tim pengusul termasuk tenaga pembantu yang melibatkan mahasiswa.

Transfer ipteks pembuatan mesin pelet dan pembuatan nugget ikan lele. Transfer ipteks pembuatan mesin pelet lele dan pembuatan nugget ikan lele dilakukan dengan mengajarkan kepada mitra cara pembuatanmenggunakan mesin pelet, praktek pembuatan pelet ikan dan proses pembuatan produk nugget lele dari bahan baku ikan lele sampai dengan pengemasan nugget ikan lele sayur.

\section{B. Pelatihan Penggunaan Mesin Pelet}

Setelah alat selesai dibuat, maka mesin akan diserahkan kepada mitra usaha dan diberikan pelatihan cara pengoperasian alat tersebut. Pelatihan pengoperasionalan mesin pelet ikan untuk mitra 1 akan dilaksanakan di lokasi mitra 1 yaitu kecamatan Sungai Raya, Kabupaten Kubu Raya. Sedangkan untuk mitra 2 akan dilaksanakan di lokasi mitra 2 yaitu di Kecamatan Mempawah Hilir Kabupaten Pontianak.

\section{Pelatihan pembuatan pelet ikan}

Pelatihan pengoperasian alat dilaksanakan bersamaan dengan pelatihan pembuatan pelet ikan..

\section{Penyerahan alat pembuatan nugget lele}

Salah satu kegiatan yang akan dilakukan pada saat kegiatan ini adalah penyerahan alat-alat yang digunakan dalam proses pembuatan nugget ikan lele sayur, diantaranya adalah: Mesin Pengaduk/Penghancur ikan, dan vacuum sealer, dsb.

\section{E. Pelatihan pembuatan nugget lele}

Pelatihan pembuatan nugget ikan lele sayur merupakan kegiatan yang akan dilaksanankan pada saat kegiatan

\section{F. Evaluasi dan pemantauan}

Evaluasi dan pemantauan dilakukan untuk mengetahui apakah kegiatan yang dilakukan sudah mampu mengatasi permasalahan mitra atau belum. Disamping itu juga berguna untuk mengetahui 
permasalahan yang dihadapi mitra dalam hal penggunaan mesin pelet ikan, pembuatan pelet ikan, pembuatan nugget ikan lele sayur, dan pengemasan.

\section{Hasil Eksperimen}

Hasil dari kegiatan didapatkan sebagai berikut:

Tabel 1. Perbandingan Produksi sebelum dan setelah menggunakan mesin

\begin{tabular}{|c|c|}
\hline Produksi Manual & Produksi dengan Mesin \\
\hline $\begin{array}{l}\text { Awalnya biaya pakan merk } \\
\mathrm{X} \pm \text { Rp. } 140.000 / 10 \mathrm{~kg} \\
\text { Panen lele } \pm 3 \text { bulan }\end{array}$ & $\begin{array}{l}\text { Biaya pakan menjadi } \\
\pm \text { Rp. } 80.000 / 10 \mathrm{~kg} \\
\text { Panen lele } \pm 3 \text { bulan }\end{array}$ \\
\hline $\begin{array}{l}\text { Produksi nugget maksimal } \\
\pm 4 \mathrm{~kg} / \mathrm{hari} \\
\text { keuntungan kotor maksimal } \\
\pm \mathrm{Rp} .280 .000 / \mathrm{hr}\end{array}$ & $\begin{array}{l}\text { Produksi nugget minimal } \\
\pm 6 \mathrm{~kg} / \mathrm{hari}, \\
\text { keuntungan kotor minimal } \\
\pm \mathrm{Rp} .420 .000 / \mathrm{hr}\end{array}$ \\
\hline
\end{tabular}

\section{Kesimpulan}

Berdasarkan hasil yang telah dicapai, maka kesimpulan yang dapat dibuat sebagai berikut :

1. Mesin pelet ikan lele, mesin pengaduk/penghancur ikan lele, serta mesin vacuum sealer dapat dimanfaat Mitra 1 dan 2 untuk proses produksi pelet dan nugget secara higienis sehingga permasalahan yang selama ini dihadapi para mitra dapat diurai dan diselesaikan dengan baik.

2. Terjadi peningkatan produksi dan peningkatan keuntungan lebih dari $50 \%$ kepada kedua mitra setelah dilakukan bantuan alat, pelatihan dan pendampingan mitra.

3. Semua kegiatan bantuan alat, pelatihan dan pendampingan telah dilaksanakan dengan baik dan memperoleh sambutan yang sangat baik oleh kedua mitra dan ibu lurah Banjar Serasan

\section{Referensi}

[1] Mushollaeni W dan Tirtosastro S, 2007. Pengolahan Nugget Komposit dengan Bahan Baku Ampas Tahu dan Daging Ikan Hiu. Program Studi Teknologi Industri Pertanian, Fakultas Pertanian, Universitas Tribuwana Tunggadewi, Malang. Buana Sains Volume 7 Nomor 2: 131-138. 2007.

[2] Rini.. 2001. Pembuatan Nuggets Kupang Proporsi Tepung terigu serta Penambahan Kuning Telur terhadap Sifat Fisik, Kimia dan Organoleptik. Publikasi Ilmiah Jurusan Teknologi Hasil Pertanian. Universitas Brawijaya.

[3] Ultiarahman G, Harmain RM, dan Yusuf N., 2013, Karakteristik Kimia dan Organoleptik Nugget Ikan Layang (Decapterus sp.) yang Disubstitusi dengan Tepung Ubi Jalar Putih (Ipomea batatas L)., Jurusan Teknik Perikanan, Fakultas Ilmu-Ilmu Pertanian, Universitas Negeri Gorontalo. Nike: Jurnal Imliah Perikanan dan Kelautan, Volume 1, Nomor 3, Desember 2013.

\section{Biography}

${ }^{1)}$ Tri Wahyudi, lahir di Pontianak, 29 Mei 1981.Tahun 2005 dia memperoleh gelar Sarjana Teknik (ST) dari Universitas Pasundan di Bandung dengan bidang keahlian Teknik Manajemen Industri. Kemudian gelar Magister Teknik (MT) dengan bidang keahlian Teknik Manajemen Industri di peroleh dari Institut Teknologi Bandung (ITB) pada tahun 2009. Sejak tahun 2010 sampai dengan sekarang dia merupakan dosen tetap pada Program Studi Teknik Industri di Fakultas Teknik Universitas Tanjungpura.

${ }^{2)}$ Silvia Uslianti, lahir di Pontianak, 31 Agustus 1972. Tahun 1996 dia memperoleh gelar Sarjana Teknik (ST) dari Universitas Islam Indonesia di Yogyakarta dengan bidang keahlian Teknik Industri. Kemudian gelar Magister Teknik (MT) diperoleh dari Institut Teknologi Sepuluh Nopember (ITS) pada tahun 2002. Sejak tahun 1998 sampai sekarang dia merupakan dosen tetap di Program Studi Teknik Industri, Fakultas Teknik, Universitas Tanjungpura. 